\title{
Treatment patterns and outcomes of older patients with mantle cell lymphoma in an Asian population
}

\author{
Xinyi Yang ${ }^{1}$, Lay Poh Khoo ${ }^{2}$, Esther Wei Yin Chang ${ }^{2,3}$, Valerie Shiwen Yang 2,3,4 Eileen Poon ${ }^{2,3,5}$, \\ Nagavalli Somasundaram ${ }^{2,3,5}$, Mohamad Farid ${ }^{2,3,5}$, Tiffany Pooi Ling Tang ${ }^{2,3,5}$, Miriam Tao 2,3,5, \\ Soon Thye Lim ${ }^{2,3,5^{*}}$ and Jason Yongsheng Chan ${ }^{2,3,5,6^{*}}$ (D)
}

\begin{abstract}
Background: Significant progress has been made in the treatment outcomes of mantle cell lymphoma (MCL) since the introduction of cytarabine and rituximab in modern regimens. However, older patients may not readily tolerate these agents nor derive benefit. We investigated the impact of age on treatment patterns and clinical outcomes of MCL patients in an Asian population.
\end{abstract}

Methods: A retrospective study was conducted on patients $(n=66)$ diagnosed with MCL at the National Cancer Centre Singapore between 1998 and 2018. The median follow-up duration was 40 months. Survival analyses were performed using the Kaplan-Meier method and multivariate Cox proportional models.

Results: The median age of the cohort was 59 years (range, 26-84), with a male predominance (73\%). The majority (86\%) had advanced stage 3-4 disease at diagnosis. Compared with younger patients, older patients aged $\geq 60$ years $(n=32 ; 48.5 \%)$ presented more frequently with B-symptoms ( $75 \%$ vs $38 \%, p=0.0028)$, anaemia (75\% vs $35 \%$, $p=0.0013$ ), and carried higher prognostic risk scores (sMIPI high risk $84 \%$ vs $56 \%, p=0.016$ ). Non-cytarabine-based induction chemotherapy was more commonly administered in older patients ( $76 \%$ vs $32 \%, p=0.0012$ ). The 5 -year overall survival (OS) and progression-free survival (PFS) was 68 and $25 \%$ respectively. In a multivariable model, older age ( $\mathrm{HR} 3.42,95 \% \mathrm{Cl} 1.48-7.92, p=0.004$ ) and anemia ( $\mathrm{HR} 2.56,95 \% \mathrm{Cl} 1.10-5.96, p=0.029$ ) were independently associated with poorer OS while older age (HR 2.24,95\%Cl 1.21-4.14, $p=0.010$ ) and hypoalbuminemia (HR 2.20, $95 \% \mathrm{Cl} 1.17-4.13, p=0.014)$ were independently associated with poorer PFS. In an exploratory analysis, maintenance rituximab following induction chemotherapy improved PFS in younger patients, with median PFS of 131 months and 45 months with or without maintenance therapy respectively ( $\mathrm{HR} 0.39,95 \% \mathrm{Cl} 0.16-0.93, p=0.035)$. In contrast, no survival benefit was observed in older patients.

Conclusions: We demonstrated in our analysis that older patients with MCL may harbor adverse clinical features and may not derive benefit from maintenance rituximab, highlighting the need for further research in this area of need.

Keywords: Prognostic biomarker, Cytarabine, Non-Hodgkin lymphoma, Chemotherapy

\footnotetext{
* Correspondence: lim.soon.thye@singhealth.com.sg;

Jason.chan.y.s@nccs.com.sg

${ }^{2}$ Division of Medical Oncology, National Cancer Centre Singapore, 11

Hospital Drive, Singapore City 169610, Singapore

Full list of author information is available at the end of the article
}

(C) The Author(s). 2021 Open Access This article is licensed under a Creative Commons Attribution 4.0 International License, which permits use, sharing, adaptation, distribution and reproduction in any medium or format, as long as you give appropriate credit to the original author(s) and the source, provide a link to the Creative Commons licence, and indicate if changes were made. The images or other third party material in this article are included in the article's Creative Commons licence, unless indicated otherwise in a credit line to the material. If material is not included in the article's Creative Commons licence and your intended use is not permitted by statutory regulation or exceeds the permitted use, you will need to obtain permission directly from the copyright holder. To view a copy of this licence, visit http://creativecommons.org/licenses/by/4.0/ The Creative Commons Public Domain Dedication waiver (http://creativecommons.org/publicdomain/zero/1.0/) applies to the data made available in this article, unless otherwise stated in a credit line to the data. 
Table 1 Clinical and demographic characteristics of patients with MCL in our cohort

\begin{tabular}{ll}
\hline Characteristic & $\boldsymbol{N}(\%)$ \\
\hline Total & $66(100)$ \\
Age (years) & \\
$\quad$ Median (range) & $59(26$ to 84$)$ \\
$\geq \mathbf{6 0}$ & $32(48.5)$ \\
$<60$ & $34(51.5)$ \\
Sex & \\
Male & $48(72.7)$ \\
Female & $18(27.3)$ \\
Ethnicity & \\
Chinese & $50(75.8)$ \\
Malay & $7(10.6)$ \\
Indian & $3(4.55)$ \\
Others & $6(13.6)$ \\
Smoking history & \\
Yes & $9(13.6)$ \\
No & $57(86.4)$
\end{tabular}

B-symptoms

Absent

45 (68.2)

Present

ECOG performance status

0

1-4

$40(60.6)$

$26(39.4)$

Ann Arbor stage

1-2

3-4

sMIPI risk

Low

Intermediate

High

Bulky disease $>10 \mathrm{~cm}$

Yes

No

Spleen involved

Yes

20 (30.3)

No

Number of nodal sites

0-3

$\geq 4$

Extra-nodal involvement

Yes

No

$9(18.2)$

$57(86.4)$

$20(30.3)$

$30(45.5)$

$16(24.2)$

$6(9.5)$

57 (90.5)

$46(69.7)$

$26(39.4)$

$40(60.6)$

$54(81.8)$

$12(18.2)$

Bone marrow involvement

Positive
Table 1 Clinical and demographic characteristics of patients with $\mathrm{MCL}$ in our cohort (Continued)

\begin{tabular}{|c|c|}
\hline Characteristic & $N(\%)$ \\
\hline Negative & $25(37.9)$ \\
\hline \multicolumn{2}{|c|}{ Ki-67 expression (\%) } \\
\hline$>30$ & $22(47.8)$ \\
\hline$\leq \mathbf{3 0}$ & $24(52.2)$ \\
\hline \multicolumn{2}{|l|}{ Serum $L D H$} \\
\hline Elevated & $35(54.7)$ \\
\hline Not elevated & $29(45.3)$ \\
\hline \multicolumn{2}{|l|}{ Albumin ( $g / L)$} \\
\hline$<35$ & $18(27.7)$ \\
\hline$\geq 35$ & $47(72.3)$ \\
\hline \multicolumn{2}{|c|}{ Hemoglobin ( $g / d L)$} \\
\hline$\leq 12.4$ & $36(54.5)$ \\
\hline$>12.4$ & $30(45.5)$ \\
\hline \multicolumn{2}{|l|}{$W B C\left(10^{9}\right.$ cells/L) } \\
\hline$>10$ & $19(28.8)$ \\
\hline$\leq 10$ & $47(71.2)$ \\
\hline
\end{tabular}

Abbreviations: ECOG Eastern Cooperative Oncology Group, MIPI Mantle Cell International Prognostic Index, $L D H$ lactate dehydrogenase, WBC white blood cell count

Variables unknown include: presence of bulky disease $>10 \mathrm{~cm}(n=3), \mathrm{Ki}-67$ expression $(n=20)$, serum albumin $(n=1)$, serum $\operatorname{LDH}(n=2)$

\section{Introduction}

Mantle cell lymphoma (MCL) is a rare B cell nonHodgkin lymphoma characterized by distinct genetic alterations and immunophenotype [1]. Clinically, majority of MCL cases occur in the male gender and older patients [2]. Although it is recognized that the clinical course and treatment responses often exhibit significant heterogeneity, this disease entity is typically aggressive and portends a poor prognosis [3].

Contemporary treatment for MCL constitutes a choice of various induction chemotherapy regimens followed by a consideration for autologous stem cell transplant (auto-SCT) and/or maintenance rituximab (MR), with the ultimate decision depending largely on patient factors as well as disease biology. For young and fit patients, the administration of intensive rituximab-based immuno-chemotherapy regimens incorporating high-dose cytarabine with or without autoSCT are accepted first line treatment options [4-7]. The management of the older patient with MCL remains highly challenging, as the majority these patients are not candidates for such intensive treatment regimens. Alternative lessintensive induction strategies, including $\mathrm{R}-\mathrm{CHOP}$ and $\mathrm{R}$ bendamustine are generally preferred for this group of patients provided they are not frail [2]. The use of MR remains an option, though the derived benefit may depend on the initial choice of induction therapy $[8,9]$. 
Table 2 Association of age at diagnosis with clinical characteristics

\begin{tabular}{|c|c|c|c|}
\hline \multirow[t]{2}{*}{ Characteristic } & \multicolumn{2}{|l|}{ Age (years) } & \multirow[t]{2}{*}{$p$-value } \\
\hline & $\geq 60$ & $<60$ & \\
\hline Total & $32(48.5 \%)$ & $34(51.5 \%)$ & - \\
\hline \multicolumn{4}{|l|}{ Sex } \\
\hline Male (48) & $24(75 \%)$ & $24(70.6 \%)$ & 0.6898 \\
\hline Female (18) & $8(25 \%)$ & $10(29.4 \%)$ & \\
\hline \multicolumn{4}{|l|}{ Ethnicity } \\
\hline Chinese (50) & $23(71.9 \%)$ & $27(79.4 \%)$ & 0.4786 \\
\hline Other (16) & $9(28.1 \%)$ & $7(20.6 \%)$ & \\
\hline \multicolumn{4}{|l|}{ Smoking history } \\
\hline Yes (9) & $4(12.5 \%)$ & $5(14.7 \%)$ & 1.0000 \\
\hline No (57) & $28(87.5 \%)$ & $29(85.3 \%)$ & \\
\hline \multicolumn{4}{|l|}{ B-symptoms } \\
\hline Absent (29) & $8(25 \%)$ & $21(61.8 \%)$ & 0.0028 \\
\hline Present (37) & $24(75 \%)$ & $13(38.2 \%)$ & \\
\hline \multicolumn{4}{|l|}{ ECOG performance status } \\
\hline $0(40)$ & $16(50 \%)$ & $24(70.6 \%)$ & 0.0896 \\
\hline $1-4(26)$ & $16(50 \%)$ & $10(29.4 \%)$ & \\
\hline \multicolumn{4}{|l|}{ Ann Arbor stage } \\
\hline 1-2 (9) & $4(12.5 \%)$ & $5(14.7 \%)$ & 1.0000 \\
\hline $3-4(57)$ & $28(87.5 \%)$ & $29(85.3 \%)$ & \\
\hline \multicolumn{4}{|l|}{ sMIPI risk } \\
\hline Low/intermediate (20) & $5(15.6 \%)$ & $15(44.1 \%)$ & 0.0161 \\
\hline High (46) & $27(84.4 \%)$ & 19 (55.9\%) & \\
\hline \multicolumn{4}{|l|}{ Bulky disease $>10 \mathrm{~cm}$} \\
\hline Yes (6) & $3(9.38 \%)$ & $3(8.82 \%)$ & 1.0000 \\
\hline No (57) & $28(87.5 \%)$ & $29(85.3 \%)$ & \\
\hline \multicolumn{4}{|l|}{ Spleen involved } \\
\hline Yes (20) & $10(31.3 \%)$ & $10(29.4 \%)$ & 0.8720 \\
\hline No (46) & $22(68.8 \%)$ & $24(70.6 \%)$ & \\
\hline \multicolumn{4}{|l|}{ Number of nodal sites } \\
\hline 0-3 (26) & $11(34.4 \%)$ & $15(44.1 \%)$ & 0.4217 \\
\hline$\geq \mathbf{4}(40)$ & $21(65.6 \%)$ & $19(55.9 \%)$ & \\
\hline \multicolumn{4}{|l|}{ Extra-nodal involvement } \\
\hline Yes (54) & $24(75 \%)$ & $30(88.2 \%)$ & 0.2095 \\
\hline No (12) & $8(25 \%)$ & $4(11.8 \%)$ & \\
\hline \multicolumn{4}{|l|}{ Bone marrow involvement } \\
\hline Positive (41) & $17(53.1 \%)$ & $24(70.6 \%)$ & 0.1469 \\
\hline Negative (25) & $15(46.9 \%)$ & $10(29.4 \%)$ & \\
\hline \multicolumn{4}{|l|}{ Ki-67 expression (\%) } \\
\hline$>\mathbf{3 0}(22)$ & $12(37.5 \%)$ & $10(29.4 \%)$ & 0.5593 \\
\hline$\leq \mathbf{3 0}(24)$ & $11(34.4 \%)$ & $13(38.2 \%)$ & \\
\hline \multicolumn{4}{|l|}{ Serum $L D H$} \\
\hline Elevated (35) & $18(56.3 \%)$ & $17(50 \%)$ & 0.4262 \\
\hline Not elevated (29) & $12(37.5 \%)$ & $17(50 \%)$ & \\
\hline
\end{tabular}


Table 2 Association of age at diagnosis with clinical characteristics (Continued)

\begin{tabular}{|c|c|c|c|}
\hline Characteristic & Age (years) & & $p$-value \\
\hline \multicolumn{4}{|l|}{ Albumin $(g / L)$} \\
\hline$<35(18)$ & $11(34.4 \%)$ & 7 (20.6\%) & 0.1835 \\
\hline$\geq 35$ (47) & $20(62.5 \%)$ & $27(79.4 \%)$ & \\
\hline \multicolumn{4}{|c|}{ Hemoglobin ( $g / d L)$} \\
\hline$\leq 12.4(36)$ & $24(75 \%)$ & $12(35.3 \%)$ & 0.0013 \\
\hline$>12.4(30)$ & $8(25 \%)$ & $22(64.7 \%)$ & \\
\hline \multicolumn{4}{|c|}{ WBC $\left(10^{9}\right.$ cells/L $)$} \\
\hline$>10(19)$ & $10(31.3 \%)$ & $9(26.5 \%)$ & 0.6706 \\
\hline$\leq 10(47)$ & $22(68.8 \%)$ & $25(73.5 \%)$ & \\
\hline
\end{tabular}

Variables unknown include: presence of bulky disease $>10 \mathrm{~cm}(n=3)$, Ki-67 expression $(\mathrm{n}=20)$, serum albumin $(n=1)$, serum LDH $(n=2)$

Table 3 First line chemotherapy and response

\begin{tabular}{|c|c|c|c|}
\hline \multirow[t]{3}{*}{ Treatment modality } & \multicolumn{3}{|l|}{$N(\%)$} \\
\hline & & \multicolumn{2}{|c|}{ Response to chemotherapy - $n(\%)$} \\
\hline & & PR & CR \\
\hline Cytarabine-based & $27(40.9)$ & $5(18.5)$ & $22(81.5)$ \\
\hline R-CHOP/R-ARAC & $6(9.1)$ & $2(33.3)$ & $4(66.7)$ \\
\hline R-CHOP/R-DHAP & $1(1.5)$ & - & $1(100)$ \\
\hline R-HyperCVAD & $16(59.3)$ & $1(6.25)$ & $15(93.8)$ \\
\hline HyperCVAD & $2(3.0)$ & $1(50)$ & $1(50)$ \\
\hline R-BAC & $2(3.0)$ & $1(50)$ & $1(50)$ \\
\hline Others & $29(51.8)$ & $8(27.5)$ & $19(65.5)$ \\
\hline R-Bendamustine & $7(10.6)$ & $2(28.6)$ & $5(71.4)$ \\
\hline VRCAP & $3(4.5)$ & - & $3(100)$ \\
\hline $\mathrm{R}-\mathrm{CHOP}{ }^{\mathrm{a}}$ & $16(24.2)$ & $4(25)$ & $10(62.5)$ \\
\hline R-CVP & $1(1.5)$ & $1(100)$ & - \\
\hline $\mathrm{CHOP}$ & $2(3.0)$ & $1(50)$ & $1(50)$ \\
\hline \multicolumn{4}{|l|}{ Maintenance rituximab } \\
\hline Yes & $25(44.6)$ & & \\
\hline No & $31(55.4)$ & & \\
\hline \multicolumn{4}{|c|}{ Autologous stem cell transplant } \\
\hline Yes & $5(7.6)$ & & \\
\hline No & $61(92.4)$ & & \\
\hline \multicolumn{4}{|l|}{ Non-chemotherapy } \\
\hline Watch and wait only & $1(1.8)$ & & \\
\hline Radiation only & $3(4.6)$ & & \\
\hline Best Supportive Care & $3(4.6)$ & & \\
\hline Unknown & $3(4.6)$ & & \\
\hline
\end{tabular}

Responses were unknown for 2 patients 
In this study, we investigate the clinical outcomes of MCL patients in an Asian population and examine the impact of age on their treatment patterns and clinical outcomes.

\section{Patients and methods}

\section{Study cohort}

Patients who were diagnosed with MCL and seen at the National Cancer Centre Singapore between April 1998 and June 2018 were retrospectively analysed. A total of 66 patients were included in the final analysis. The median follow-up duration was 39.6 months. Relevant demographical, clinico-pathological and haematological information were collected and utilized for the analysis. Demographical information included sex, age, ethnicity and smoking history. Age, sex, and ethnicity of the patients were corroborated against their National Registry Identification Cards. Clinical characteristics included the presence of B-symptoms, Eastern Cooperative Oncology Group (ECOG) performance status, Ann Arbor staging, sites and bulk of disease, as well as simplified MIPI risk scores (sMIPI). Haematological characteristics included peripheral blood haemoglobin $(\mathrm{Hb})$ and leucocyte (WBC) counts, serum lactate dehydrogenase (LDH) levels and serum albumin levels. Treatment information was also collected for analysis, including the choice of first linechemotherapy, use of MR, and conduct of autologous stem cell transplantation.

All data were obtained at the time of diagnosis or subsequent follow-up. Written informed consent for use of biospecimens and clinical data were obtained in accordance with the Declaration of Helsinki. The research study was carried out as part of the Singapore Lymphoma Study with approval from the SingHealth Centralised Institutional Review Board (CIRB 2018/3084). Participants and/or their legal guardians provided informed consent for their data to be used in this research. The datasets created and analysed during this study are available from the corresponding authors upon reasonable request.

\section{Statistical analysis}

The primary outcomes of this study are overall survival (OS) and progression-free survival (PFS). OS was calculated from the date of diagnosis up to the date of death from any cause or was censored at the date of last followup for survivors. PFS was defined as the time elapsed between the date of diagnosis to the date of relapse, progression, or death from any cause. Kaplan-Meier survival curves were plotted to estimate survival for each individual clinico-pathological parameter. The log-rank test was then used to determine hazard ratios (HR), the corresponding $95 \%$ confidence intervals $(95 \% \mathrm{CI})$ of mortality and the $p$-values. Subsequently, parameters with significance level of $<0.05$ were used in the generation of multivariable Cox regression models via a backward regression approach to test for independence of significant factors. Comparisons of the frequencies of categorical variables were performed using Pearson's Chi-squared test or Fisher's exact test, as appropriate. All statistical evaluations were made assuming a two-sided test with significance level of 0.05 unless otherwise stated. All tests were performed using MedCalc statistical Software for Windows version 19.0.4 (MedCalc Software, Ostend, Belgium).

\section{Results}

\section{Patient demographics}

A total of 66 patients were included in the study. The median age of diagnosis was 59 years (range: 26 to 84 years). Forty-eight (72.7\%) were male and 18 (27.3\%) were female. In terms of initial staging, 9 (18.2\%) patients were Ann-Arbor stage 1-2 at diagnosis while 57 (86.4\%) were stage 3-4; 41 (62.1\%) had bone marrow involvement. Twenty (30.3\%) patients were classified as low risk, 30 (45.5\%) as intermediate risk, and $16(24.2 \%)$ as high risk by the sMIPI prognostic index. Clinical and demographic characteristics of all patients are summarized in Table 1.

Patients were analysed by age groups (Table 2). There were $32(48.5 \%)$ and $34(51.5 \%)$ patients with age $\geq 60$ years and age $<60$ years, respectively. Compared with younger patients, older patients $(\mathrm{age} \geq 60)$ presented more frequently with B-symptoms at diagnosis $(75 \%$ vs

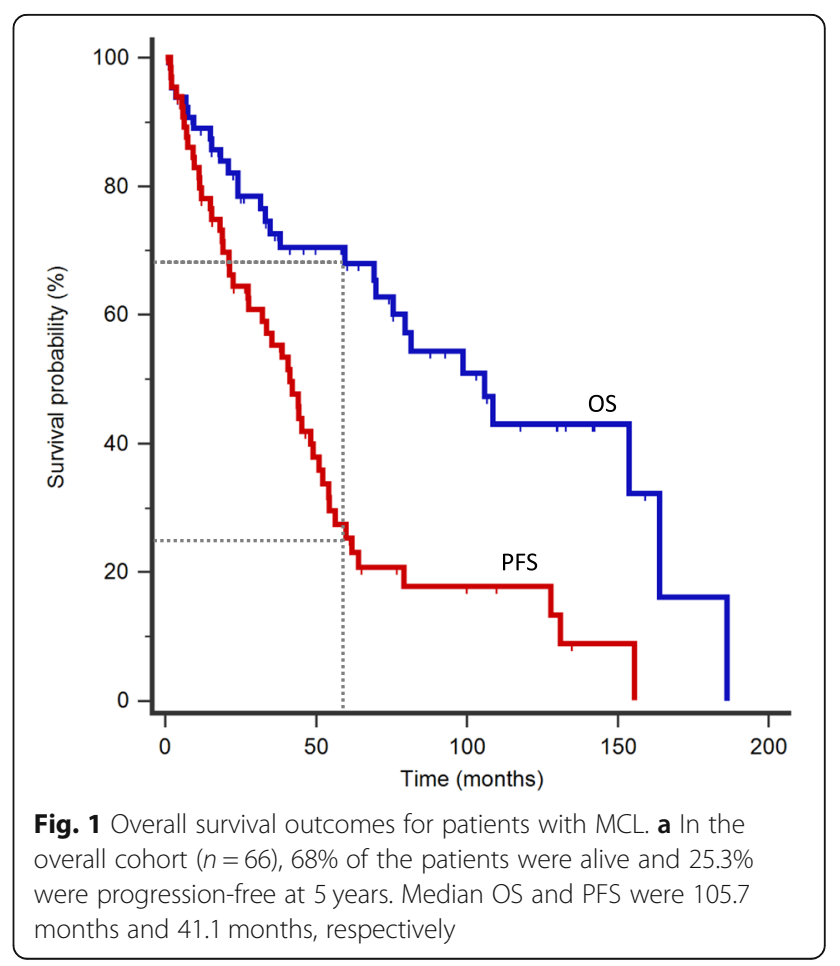


$38.2 \%, p=0.0028)$. A higher proportion of these older patients were classified as sMIPI high risk $(84.4 \%$ vs $55.9 \%, p=0.016$ ), and anaemia was significantly more prevalent $(75 \%$ vs $35.3 \%, p=0.0013)$. Older patients tended to have poorer performance status as well, though this was not statistically significant.

\section{Treatment patterns and outcomes}

Fifty-six patients $(84.8 \%)$ received chemotherapy as firstline treatment, amongst which $25(44.6 \%)$ were age $\geq 60$ years and $31(55.4 \%)$ were age $<60$ years. In this subgroup analysis, older patients were also more commonly in the sMIPI high risk group ( $84 \%$ vs $54.8 \%, p=0.024)$ and more frequently anaemic ( $68 \%$ vs $35.5 \%, p=0.017)$ (Table S1).

In terms of chemotherapy regimens (Table 3), 27 (48.2\%) received cytarabine-based regimens with a complete response rate of $81.5 \%$ and partial response rate of $18.5 \%$. Twenty-nine patients $(51.8 \%)$ received noncytarabine-based chemotherapy, achieving a complete response rate of $65.5 \%$ and partial response rate of $27.5 \%$.

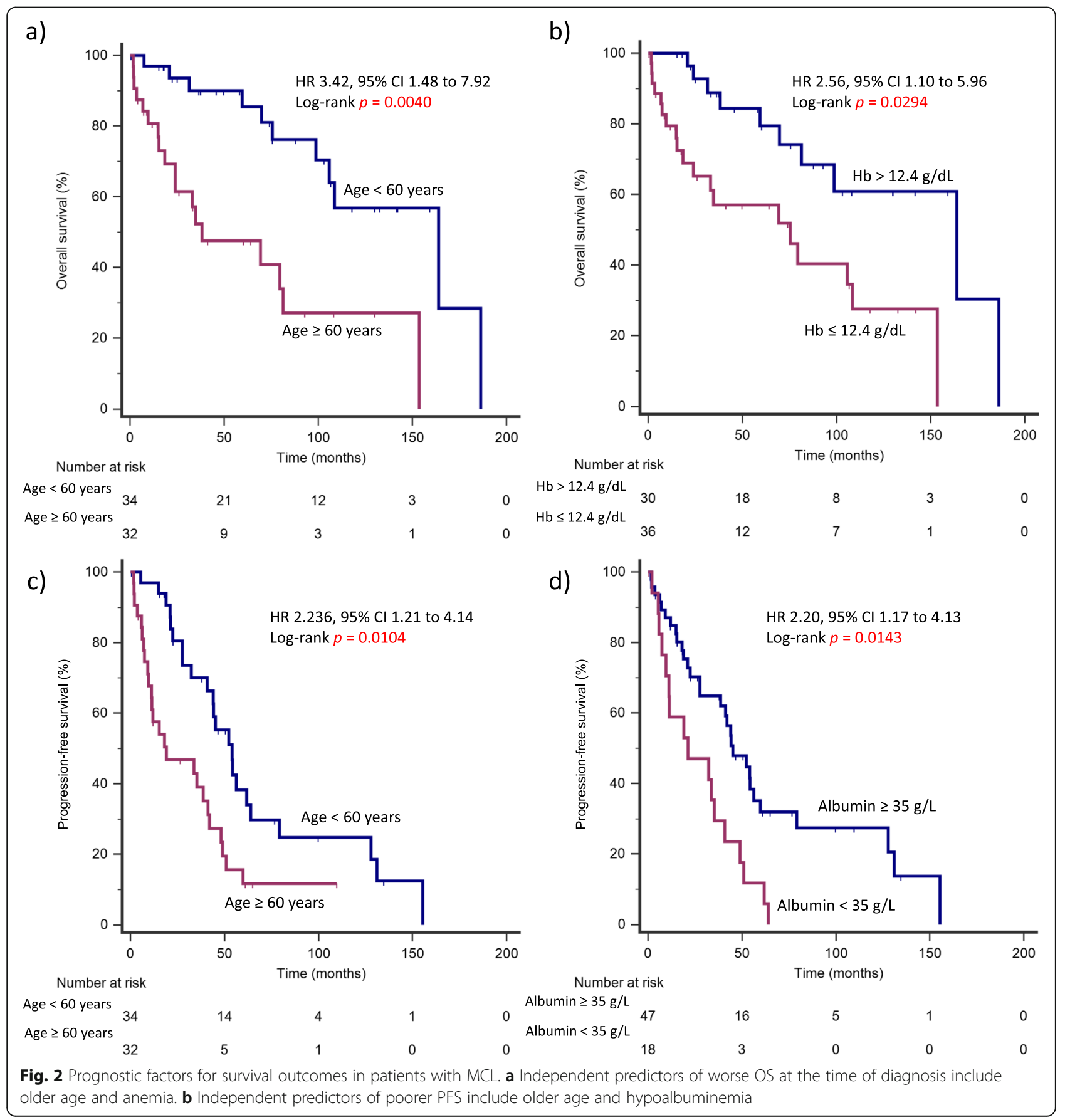


Table 4 Univariate survival analysis for entire cohort

\begin{tabular}{|c|c|c|c|c|c|c|}
\hline \multirow[t]{2}{*}{ Characteristic } & \multicolumn{3}{|c|}{ Overall survival } & \multicolumn{3}{|c|}{ Progression-free survival } \\
\hline & $\mathrm{HR}$ & $95 \% \mathrm{Cl}$ & $p$-value & HR & $95 \% \mathrm{Cl}$ & $p$-value \\
\hline Age $\geq 60$ years & 4.30 & 1.92 to 9.63 & 0.0004 & 2.61 & 1.40 to 4.87 & 0.0025 \\
\hline Sex (male) & 1.00 & 0.44 to 2.29 & 0.9994 & 0.94 & 0.50 to 1.77 & 0.8554 \\
\hline Ethnicity (Chinese) & 0.73 & 0.29 to 1.87 & 0.5160 & 0.86 & 0.42 to 1.75 & 0.6750 \\
\hline Smoking history present & 1.01 & 0.30 to 3.38 & 0.9910 & 0.73 & 0.30 to 1.80 & 0.4964 \\
\hline B-symptoms present & 1.93 & 0.87 to 4.29 & 0.1061 & 1.26 & 0.68 to 2.34 & 0.4711 \\
\hline ECOG 1-4 & 2.53 & 1.12 to 5.71 & 0.0261 & 1.84 & 0.97 to 3.48 & 0.0608 \\
\hline Bulky disease $>10 \mathrm{~cm}$ & 0.56 & 0.14 to 2.34 & 0.4300 & 0.71 & 0.26 to 1.96 & 0.5136 \\
\hline sMIPI intermediate-high & 1.50 & 0.68 to 3.32 & 0.3184 & 1.43 & 0.79 to 2.60 & 0.2423 \\
\hline Ann Arbor stage 3-4 & 0.60 & 0.21 to 1.72 & 0.3398 & 1.22 & 0.55 to 2.72 & 0.6314 \\
\hline Lymph node involvement $\geq \mathbf{4}$ & 0.47 & 0.21 to 1.03 & 0.0598 & 0.99 & 0.55 to 1.78 & 0.9649 \\
\hline Extra-nodal involvement & 0.52 & 0.17 to 1.56 & 0.2454 & 0.73 & 0.31 to 1.70 & 0.4621 \\
\hline Bone marrow involvement & 0.46 & 0.20 to 1.03 & 0.0586 & 0.59 & 0.32 to 1.11 & 0.1029 \\
\hline Spleen involvement & 0.50 & 0.22 to 1.16 & 0.1081 & 0.91 & 0.48 to 1.73 & 0.7723 \\
\hline Serum LDH elevated & 1.02 & 0.46 to 2.27 & 0.9529 & 1.59 & 0.88 to 2.87 & 0.1240 \\
\hline $\mathrm{Hb} \leq 12.4 \mathrm{~g} / \mathrm{dL}$ & 3.05 & 1.42 to 6.57 & 0.0044 & 2.02 & 1.12 to 3.64 & 0.0190 \\
\hline WBC $>10 * 10^{9}$ cells $/ \mathrm{L}$ & 1.54 & 0.64 to 3.68 & 0.3311 & 1.24 & 0.64 to 2.40 & 0.5147 \\
\hline Albumin $<35 \mathrm{~g} / \mathrm{L}$ & 1.71 & 0.70 to 4.17 & 0.2412 & 3.11 & 1.48 to 6.51 & 0.0026 \\
\hline
\end{tabular}

Abbreviations: ECOG Eastern Cooperative Oncology Group

Cytarabine-based induction chemotherapy was more commonly administered in younger compared to older patients $(67.7 \%$ vs $24 \%, p=0.0012)$. The most frequently prescribed cytarabine-based and non-cytarabine-based regimens were R-HyperCVAD (59.3\%) and R-CHOP $(24.2 \%)$ respectively. Five $(7.6 \%)$ patients were consolidated with auto-SCT following complete response to induction chemotherapy. Out of 56 patients who underwent chemotherapy, 25 (44.6\%) received MR. Eleven patients (44\%) were age $\geq 60$ years and $14(56 \%)$ were age $<60$ years. Most patients receiving MR followed cytarabinebased or R-CHOP induction (age $<60$ years: 10 of 14; age $\geq 60$ years: 8 of 11 ).

\section{Survival analyses and prognostic factors}

At the time of data analysis, 22 patients (33.3\%) had died. The 5-year OS and PFS of the global series was 68 and 25.3\% respectively. Median OS and PFS were 105.7 months and 41.1 months, respectively (Fig. 1). In univariate analysis, age $\geq 60$ years (HR 4.30, 95\% CI 1.92-9.63, $p=0.0004$ ), ECOG status 1-4 (HR 2.53, 95\% CI 1.12-
5.71, $p=0.026)$ and $\mathrm{Hb} \leq 12.4 \mathrm{~g} / \mathrm{dL}(\mathrm{HR} 3.05,95 \% \mathrm{CI}$ 1.42-6.57, $p=0.0044)$ were significantly correlated with worse OS. In terms of PFS, age $\geq 60$ years (HR 2.61, 95\% CI $1.40-4.87, p=0.0025), \mathrm{Hb} \leq 12.4 \mathrm{~g} / \mathrm{dL}$ (HR 2.02, 95\% CI $1.12-3.64, p=0.19)$ and albumin $<35 \mathrm{~g} / \mathrm{L}$ (HR 3.11, 95\% CI 1.48-6.51, $p=0.0026)$ were predictive of poorer outcomes (Fig. 2 and Table 4).

A multivariate model adjusted for significant clinicopathological parameters for OS and PFS was created. Age $\geq 60$ years (HR 3.42, 95\% CI 1.48-7.92, $p=0.004$ ) and $\mathrm{Hb} \leq 12.4 \mathrm{~g} / \mathrm{dL}$ (HR 2.56, 95\% CI 1.10-5.96, $p=0.029)$ were independently associated with poorer OS while age $\geq$ 60 years (HR 2.24, 95\% CI 1.21-4.14, $p=0.010$ ) and albumin $<35$ g/L (HR 2.20, 95\% CI 1.17-4.13, $p=0.014$ ) were independently associated with poorer PFS (Table 5 ).

\section{Lack of survival benefit of maintenance rituximab in older patients}

In an exploratory analysis, we demonstrated that MR following induction chemotherapy improved PFS in younger patients (age $<60$ years), with median PFS of

Table 5 Cox's multivariate survival analysis

\begin{tabular}{llllllll}
\hline Characteristic & \multicolumn{2}{l}{ Overall survival } & & \multicolumn{3}{l}{ Progression-free survival } \\
\cline { 2 - 4 } & HR & $95 \% \mathrm{Cl}$ & $p$-value & & HR & $95 \% \mathrm{Cl}$ & $p$-value \\
\hline Age $\geq 60$ years & 3.42 & 1.48 to 7.92 & 0.0040 & 2.24 & 1.21 to 4.14 & 0.0104 \\
Albumin $<35 \mathrm{~g} / \mathrm{L}$ & - & - & - & 2.20 & 1.17 to 4.13 & 0.0143 \\
$\mathrm{Hb} \leq 12.4 \mathrm{~g} / \mathrm{dL}$ & 2.56 & 1.10 to 5.96 & 0.0294 & - & - & - \\
\hline
\end{tabular}


130.9 months and 45.2 months with and without maintenance therapy respectively (HR 0.39 , 95\% CI $0.16-$ $0.93, p=0.0346)$. In contrast, this benefit was not observed in patients $\geq 60$ years, with median PFS of 33.5 months and 38.7 months with and without maintenance therapy, respectively (Fig. 3). MR conferred a nonstatistically significant improvement in OS in patients < 60 years, with median OS being 163.8 months and 105.7 months with and without maintenance therapy, respectively (HR $0.36,95 \%$ CI $0.10-1.26, p=0.1097$ ). For patients $\geq 60$ years, there was no benefit of MR observed on OS, with median OS being 79.4 months and 69.2 months with and without maintenance therapy, respectively (Fig. S1).

\section{Discussion}

Contemporary frontline treatment of MCL involves the use of one of several multimodality immunochemotherapy regimens, with intensity modulated against age and fitness of the patient. Younger and fit patients typically receive rituximab and cytarabine-based induction, often followed by high-dose chemotherapy and auto-SCT [5, 6]. Such intensive regimens are unsuitable for the majority of patients who are older and less fit, though they still benefit from rituximab-containing, non-cytarabine-based chemotherapy such as R-CHOP [8], R-bendamustine [10] or VRCAP [11], as well as regimens containing lower doses of cytarabine such as R-BAC500 [12]. In keeping with this approach, our cohort of MCL patients were treated in a similar fashion, with older patients being treated more often with non-cytarabine-based induction chemotherapy. As demonstrated in our current study and others, these older patients may harbor poor clinical characteristics and prognostic indicators, including worse performance status, B-symptoms, anaemia and high sMIPI scores [13]. Reflecting the issues above, older patients with MCL remain challenging to manage given their adverse clinical features and inability to derive benefit from intensive treatment regimens.

MR following induction therapy forms the current standard of care in several subtypes of non-Hodgkin lymphoma (NHL), including MCL $[14,15]$. In the ECOG-ACRIN Cancer Research Group study (E1496), MR prolonged PFS when compared to observation alone in patients with indolent NHL after first-line induction chemotherapy [16]. In line with this result, the PRIMA study showed that MR significantly prolonged PFS without an improvement in OS in patients with previously untreated follicular lymphoma [17]. In MCL, an early phase II pilot study by the Wisconsin Oncology Network showed that 2 years of MR may prolong PFS following a modified R-HyperCVAD first-line induction regimen [18]. A major PFS benefit was observed as well compared to observation in patients with relapsed follicular and MCL following salvage chemotherapy [19]. More recent studies have demonstrated significant survival benefit for 3 years of MR in terms of both PFS and OS in younger patients following R-DHAP induction followed by autologous stem cell transplant [20]. In older patients

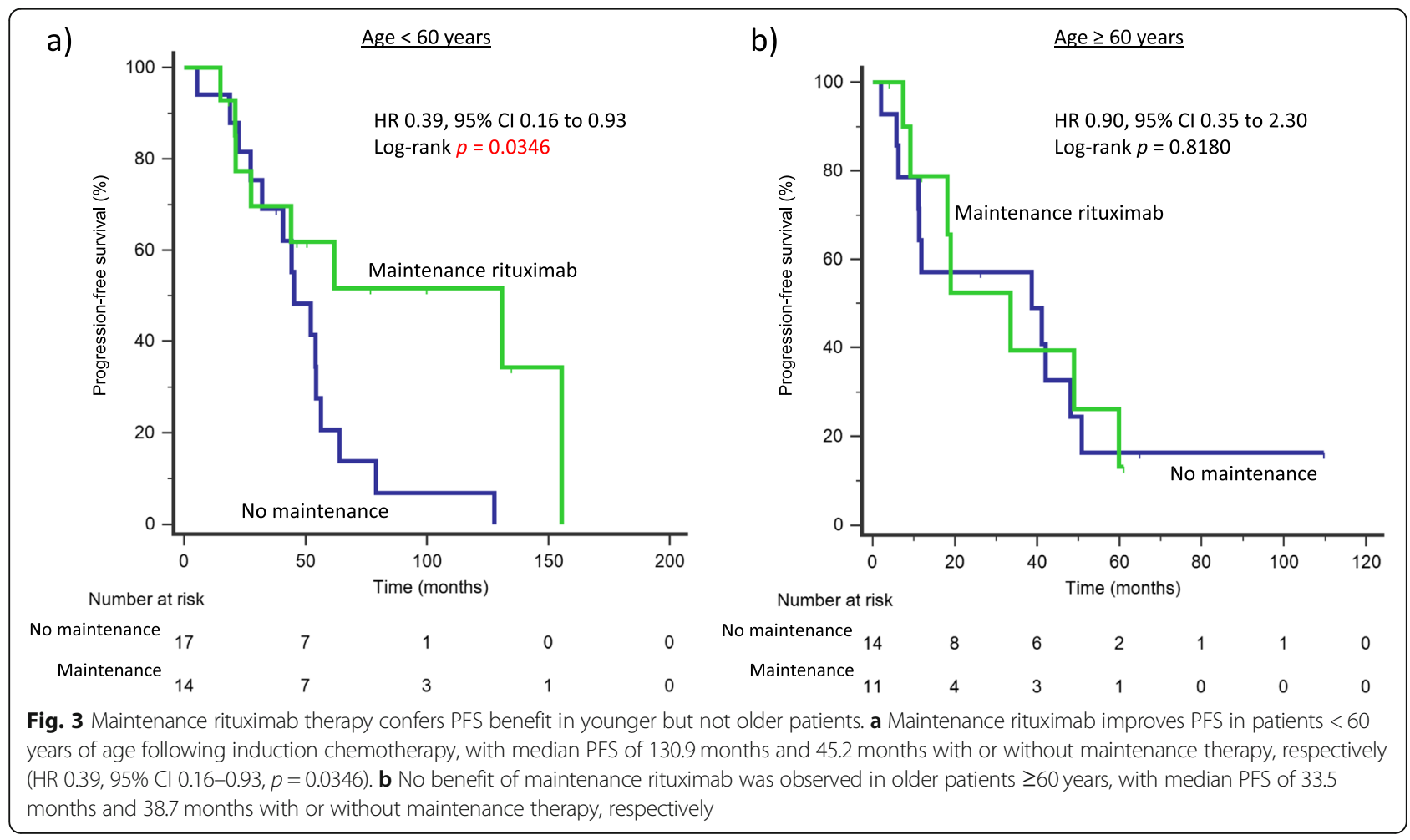


aged 60 years or older, the European MCL Network trial demonstrated that R-CHOP induction followed by MR until progression derived significantly improved PFS and OS benefit compared to maintenance interferon [8]. The benefit of MR in older patients however, appeared to depend on the type of induction used - MR followed by RFC resulted in high incidence of death in remission, mainly due to infections or secondary tumors, greatly limiting its PFS benefit [8]. In the Stil NHL7-2008 MAINTA IN trial, MR following R-bendamustine induction in a cohort of older MCL patients (median age 70 years) did not lead to significant survival benefit [9]. In our cohort, most of the patients received R-CHOP or cytarabine-based induction prior to MR, though PFS benefit was only observed in younger patients. Taken together, our results support the use of MR after R-CHOP or cytarabine-based first-line induction for younger patients.

Our current study is limited by its retrospective design and small patient cohort. Some of the information relating to prognosis such as immunohistochemical markers and molecular indicators were not available [21], and multivariate analysis may have missed some confounding factors that were not accounted for. The differences observed in baseline characteristics between older and younger patients are also preliminary and remain to be validated. In addition, the treatment received by the patients were heterogeneous, which may have affected their prognosis. Nonetheless, our study remains one of the few to describe the real-world outcomes of MCL in Asian patients. Future prospective studies in a larger cohort would be necessary to confirm our findings.

In conclusion, our study suggests that older patients with MCL may harbor adverse clinical features and may not derive benefit from maintenance rituximab, highlighting the necessity for further work in this area of unmet clinical need.

\section{Supplementary Information}

The online version contains supplementary material available at https://doi. org/10.1186/s12885-021-08326-1.

Additional file 1: Supplemental Figure S1. Maintenance rituximab therapy and OS outcomes. (a) Maintenance rituximab in patients $<60$ years of age following induction chemotherapy confers a non-statistically significant improvement in OS compared to those without maintenance therapy (median OS 163.8 months and 105.7 months, respectively) (HR $0.36,95 \% \mathrm{Cl} 0.10-1.26, p=0.1097$ ). (b) No benefit of maintenance rituximab was observed in older patients $\geq 60$ years, with median OS of 79.4 months and 69.2 months with or without maintenance therapy, respectively.

Additional file 2: Supplemental Table S1. Clinical and demographic characteristics of patients receiving chemotherapy.

\section{Acknowledgements}

The authors would like to thank all patients for their participation in this study.

\section{Authors' contributions}

$X Y$ and JYC analyzed the data and drafted the manuscript; XY, LPK, EWYC, VSY, EP, NS, MF, TPLT, MT, STL, JYC obtained patient data; XY and JYC designed the study, interpreted the results, and revised the manuscript; and all authors read and approved the final version of the manuscript.

\section{Funding}

This work was supported by the Tanoto Foundation Professorship in Medical Oncology, New Century Foundation Limited, Ling Foundation, Singapore Ministry of Health's National Medical Research Council Research Training Fellowship (NMRC/Fellowship/0054/2017), SHF-Foundation Research Grant (SHF/FG653P/2017), as well as the SingHealth Duke-NUS Academic Medical Centre and Oncology ACP Nurturing Clinician Scientist Scheme (08-FY2017/ P1/14-A28).

\section{Availability of data and materials}

The datasets created and analysed during this study are available from the corresponding authors upon reasonable request.

\section{Declarations}

Ethics approval and consent to participate

The research study was carried out as part of the Singapore Lymphoma Study with approval from the SingHealth Centralised Institutional Review Board (CIRB 2018/3084).

\section{Consent for publication}

Written informed consent for use of biospecimens and clinical data were obtained in accordance with the Declaration of Helsinki. Participants and/or their legal guardians provided informed consent for their data to be used in this research.

\section{Competing interests}

The authors declare that they have no competing interests.

\section{Author details}

${ }^{1}$ Yong Loo Lin School of Medicine, National University of Singapore, Singapore City, Singapore. ${ }^{2}$ Division of Medical Oncology, National Cancer Centre Singapore, 11 Hospital Drive, Singapore City 169610, Singapore. ${ }^{3}$ SingHealth Duke-NUS Blood Cancer Centre, Singapore City, Singapore. ${ }^{4}$ Institute of Molecular and Cell Biology, Singapore City, Singapore. ${ }^{5}$ Oncology Academic Clinical Program, Duke-NUS Medical School, Singapore City, Singapore. ${ }^{6}$ Cancer Science Institute of Singapore, National University of Singapore, Singapore City, Singapore.

Received: 27 August 2020 Accepted: 9 May 2021

Published online: 17 May 2021

\section{References}

1. Swerdlow SH, Campo E, Pileri SA, Harris NL, Stein H, Siebert R, et al. The 2016 revision of the World Health Organization classification of lymphoid neoplasms. Blood. 2016;127(20):2375-90. https://doi.org/10.1182/blood-201 6-01-643569.

2. Kluin-Nelemans JC, Doorduijn JK. What is the optimal initial management of the older MCL patient? Best Pract Res Clin Haematol. 2018;31(1):99-104. https://doi.org/10.1016/j.beha.2017.07.006

3. Vose JM. Mantle cell lymphoma: 2017 update on diagnosis, risk-stratification, and clinical management. Am J Hematol. 2017;92(8):806-13. https://doi. org/10.1002/ajh.24797.

4. Romaguera JE, Fayad L, Rodriguez MA, Broglio KR, Hagemeister FB, Pro B, et al. High rate of durable remissions after treatment of newly diagnosed aggressive mantle-cell lymphoma with rituximab plus hyper-CVAD alternating with rituximab plus high-dose methotrexate and cytarabine. J Clin Oncol. 2005;23(28):7013-2023. https://doi.org/10.1200/JCO.2005.01.1825.

5. Geisler $\mathrm{CH}$, Kolstad A, Laurell A, Andersen NS, Pedersen LB, Jerkeman M, et al. Long-term progression-free survival of mantle cell lymphoma after intensive front-line immunochemotherapy with in vivo-purged stem cell rescue: a nonrandomized phase 2 multicenter study by the Nordic Iymphoma group. Blood. 2008;112(7):2687-93. https://doi.org/10.1182/ blood-2008-03-147025. 
6. Hermine O, Hoster E, Walewski J, Bosly A, Stilgenbauer S, Thieblemont C, et al. Addition of high-dose cytarabine to immunochemotherapy before autologous stem-cell transplantation in patients aged 65 years or younger with mantle cell lymphoma (MCL younger): a randomised, open-label, phase 3 trial of the European mantle cell lymphoma Network. Lancet. 2016; 388(10044):565-75. https://doi.org/10.1016/S0140-6736(16)00739-X.

7. Gerson JN, Handorf E, Villa D, Gerrie AS, Chapani P, Li S, et al. Survival outcomes of younger patients with mantle cell lymphoma treated in the rituximab era. J Clin Oncol. 2019;37(6):471-80. https://doi.org/10.1200/JCO.1 8.00690 .

8. Kluin-Nelemans HC, Hoster E, Hermine O, Walewski J, Geisler CH, Trneny M, et al. Treatment of older patients with mantle cell lymphoma (MCL): longterm follow-up of the randomized European MCL elderly trial. J Clin Oncol. 2020;38(3):248-56. https://doi.org/10.1200/JCO.19.01294.

9. Rummel M, Knauf W, Goerner M, Soeling U, Lange E, Hertenstein B, Eggert J, Schliesser GC, Weide R, Blumenstengel K, Detlefsen N, Hinke A, Kauff F, Barth J (2016) Two years rituximab maintenance vs. observation after firstline treatment with bendamustine plus rituximab $(B-R)$ in patients with mantle cell lymphoma: First results of a prospective, randomized, multicenter phase II study (a subgroup study of the StiL NHL7-2008 MAIN TAIN trial). J Clin Oncol 34:suppl; abstr 7503 doi: https://doi.org/10.1200/ JCO.2016.34.15_suppl.7503.

10. Rummel MJ, Niederle N, Maschmeyer G, Banat GA, von Grünhagen U, Losem C, et al. Bendamustine plus rituximab versus CHOP plus rituximab as first-line treatment for patients with indolent and mantle-cell lymphomas: an open-label, multicentre, randomised, phase 3 non-inferiority trial. Lancet. 2013;381(9873):1203-10. https://doi.org/10.1016/S0140-6736(12)61763-2.

11. Robak T, Huang H, Jin J, Zhu J, Liu T, Samoilova O, Pylypenko H, Verhoef G, Siritanaratkul N, Osmanov E, Alexeeva J, Pereira J, Drach J, Mayer J, Hong X, Okamoto R, Pei L, Rooney B, van de Velde H, Cavalli F; LYM-3002 Investigators (2015) Bortezomib-based therapy for newly diagnosed mantlecell lymphoma. N Engl J Med 372:944-953. doi: https://doi.org/10.1056/ NEJMoa1412096, 10.

12. Visco C, Chiappella A, Nassi L, Patti C, Ferrero S, Barbero D, et al. Rituximab, bendamustine, and low-dose cytarabine as induction therapy in elderly patients with mantle cell lymphoma: a multicentre, phase 2 trial from Fondazione Italiana Linfomi. Lancet Haematol. 2017;4(1):e15-23. https://doi. org/10.1016/S2352-3026(16)30185-5.

13. Abrahamsson A, Dahle N, Jerkeman M. Marked improvement of overall survival in mantle cell lymphoma: a population based study from the Swedish lymphoma registry. Leuk Lymphoma. 2011;52(10):1929-35. https:// doi.org/10.3109/10428194.2011.587560.

14. Vidal L, Gafter-Gvili A, Salles G, Bousseta S, Oberman B, Rubin C, et al. Rituximab maintenance improves overall survival of patients with follicular lymphoma-individual patient data meta-analysis. Eur J Cancer. 2017;76:21625. https://doi.org/10.1016/j.ejca.2017.01.021.

15. Vidal L, Gafter-Gvili A, Dreyling M, Ghielmini M, Witzens-Harig M, Shpilberg $O$, et al. Maintenance treatment for patients with mantle cell lymphoma: a systematic review and meta-analysis of randomized trials. Hemasphere. 2018;2(4):e136. https://doi.org/10.1097/HS9.0000000000000136.

16. Hochster H, Weller E, Gascoyne RD, Habermann TM, Gordon LI, Ryan T, et al. Maintenance rituximab after cyclophosphamide, vincristine, and prednisone prolongs progression-free survival in advanced indolent lymphoma: results of the randomized phase III ECOG1496 study. J Clin Oncol. 2009;27(10): 1607-14. https://doi.org/10.1200/JCO.2008.17.1561.

17. Salles G, Seymour JF, Offner F, López-Guillermo A, Belada D, Xerri L, et al. Rituximab maintenance for 2 years in patients with high tumour burden follicular lymphoma responding to rituximab plus chemotherapy (PRIMA): a phase 3, randomised controlled trial. Lancet. 2011;377(9759):42-51. https:// doi.org/10.1016/S0140-6736(10)62175-7.

18. Kahl BS, Longo WL, Eickhoff JC, Zehnder J, Jones C, Blank J, et al. Maintenance rituximab following induction chemoimmunotherapy may prolong progression-free survival in mantle cell lymphoma: a pilot study from the Wisconsin oncology Network. Ann Oncol. 2006;17(9):1418-23. https://doi.org/10.1093/annonc/mdl127.

19. Forstpointner $\mathrm{R}$, Unterhalt $M$, Dreyling M, Böck HP, Repp R, Wandt $H$, et al. Maintenance therapy with rituximab leads to a significant prolongation of response duration after salvage therapy with a combination of rituximab, fludarabine, cyclophosphamide, and mitoxantrone (R-FCM) in patients with recurring and refractory follicular and mantle cell lymphomas: Results of a prospective randomized study of the German Low Grade Lymphoma Study
Group (GLSG). Blood. 2006;108:4003-8. https://doi.org/10.1182/blood-200604-016725.

20. Le Gouill S, Thieblemont C, Oberic L, Moreau A, Bouabdallah K, Dartigeas C, et al. Rituximab after autologous stem-cell transplantation in mantle-cell lymphoma. N Engl J Med. 2017;377(13):1250-60. https://doi.org/10.1056/ NEJMoa1701769.

21. Jain P, Wang M. Mantle cell lymphoma: 2019 update on the diagnosis, pathogenesis, prognostication, and management. Am J Hematol. 2019;94(6): 710-25. https://doi.org/10.1002/ajh.25487.

\section{Publisher's Note}

Springer Nature remains neutral with regard to jurisdictional claims in published maps and institutional affiliations.
Ready to submit your research? Choose BMC and benefit from:

- fast, convenient online submission

- thorough peer review by experienced researchers in your field

- rapid publication on acceptance

- support for research data, including large and complex data types

- gold Open Access which fosters wider collaboration and increased citations

- maximum visibility for your research: over $100 \mathrm{M}$ website views per year

At BMC, research is always in progress.

Learn more biomedcentral.com/submissions 